\title{
PENGGUNAAN FERMEN SARI DEDAK PADI \\ UNTUK PROSES PEMBUANGAN KAPUR
}

\section{Oleh : Bambang Oetojo}

\section{ABSTRACT}

This research intend to know the capabality of fermented infusion of rice bran for deliming process. The raw material used was goat "pelt" skin of 14 pieces. They were sided into two parts along the back bone and then grouped to delimed using fermented infusion of rice bran of 5 days, 10 days and 15 day respectively. Fermented infusion of rice bran used was $100^{\circ}$ on pelt weight and the duration of deliming process was 60 minutes. Phenolphthlein indica tor was used in deliming process to determine the lime streak. Practical meaning of this research is, fermented infusion of rice bran of 15 days gives thorough deliming.

\section{INTISARI}

Penelitian ini bertujuan untuk mengetahui kemampuan sari dedak padi yang difermentasikan, untuk proses pembuangan kapur Bahan mentah yang digunakan adalah kulit "pelt" kambing sebanyak 14 lembar. Kulit "pelt" tersebut dibelah menjadi dua bagian menurut garis punggung dan kemudian dikelompokkan menjadi tiga. Kelompok pertama, kedua dan ketiga diproses pembuangan kapur menggunakan sari dedak padi yang difermentasikan 5 hari, 10 hari dan 15 hari berturut-turut. Fermen sari dedak padi yang digunakan $100 \%$ dari berat kulit "pelt" dan lama proses pembuangan adalah 60 menit. Indikator phenolphthalein digunakan dalam peoses pembuangan kapur, untuk menentukan garis kapur. Arti praktis dari penelitian ini adalah, sari dedak padi yang difermentasikan selama 15 hari menghasilkan proses pembuangan kapur yang sempurna.

\section{PENDAHULUAN}

Menghilangkan kapur dari dalam kulit "pelt" merupakan salah satu tahapan proses pada penyamakan kulit, dengan tujuan mengurangi kebengkakan kulit "pelt" sebelum proses selanjutnya.

Setelah bulu dan sisa daging yang melekat dikulit dihilangkan, maka kulit tersebut dinamakan kulit "pelt" yang merupakan jaringan tiga dimensi dari fiber protein (4). Fiberkulit menyerap akali dalam bentuk kapur atau alkali yang lain. Kulit "pelt" merupakan suatu masa yang berwarna putih kebiruan, bengkak, seperti karet, dan semi tembus lihat (7). Kapur didalam kulit "pelt" digolongan dalam tiga bentuk, yaitu kalsium terikat pada kulit secara kimiawi dengan gugusan asam kolagen, sebagai kalsium yang berbentuk sabun dan sebagai kalsium tidak terikat, tetapi dalam larutan atau suspensi (2.3.4).

Kapur dan alkali yang lain didalam kulit "pelt" tidak dikehendaki lehih lama dan dalam banyak hal kapur memiliki prngaruh yang merugikan terha- 
dap bahan penyamak yang digunakan (5). Dengan bahan penyamak krom yang hersifat asam, kapur menghasilkan kulit jadi yang sifatnya keras, hijau warnanya, tidak mudah dibengkukkan dan menyebabkan penyamakan yang tidak layak. Sedang dengan bahan penyamak nabati, menghasilkan kalsium tannat pada kulit bagian permukaan, kemudian dioksidasi oleh oksigen dari udara, sehingga membentuk gugusan yang berwarna gelap (1.3.4.5)

Sebelum kulit "pelt" disamak, agar memperoleh kulit jadi yang baik, adalah perlu menghilangkan kapur dari kulit "pelt" (4.6). Demikian pula mengurang kebengkakan kulit "pelt" sampai batas yang dikehendaki, untuk menghasilkan kulit jadi yang berbeda. Menghilangkan kapur dan mengurangi kebengkakan kulit "pelt" berlangsung bersama-sama. Apabila kapur dihilangkan dari kulit "pelt", kebengkaan kulit "pelt' berkurang dalam batas pengurangan kapur (4). Tingkat menghilangkan kapur dari kulit "pelt" pada dasarnya berkaitan dengan proses berikutnya, yaitu mengatur $\mathrm{pH}$ untuk proses pengikisan protein dan mengurangi kebengkakan kuli "pelt" (3.5.7)

Jalan yang termudah untuk menghilangkan kapur adalah dengan mencuci kulit "pelt" didalam drum atau paddel yang berputar, air bersih masuk dan air kotor keluar melalui saluran yang telah ditentukan (5). Kalsium dalam larutan atau suspensi dan kalsiumdalam bentuk sabun lebih cepat dihilangkan dengan jalan mencuci kulit "pelt" (3.5.6). Tetapi hanya sebagian kapur, kira-kira 60\%, dapat dihilangkan dengan cara mencuci kulit "pelt" selama 24 jam (4). Adalah berbahaya mencuci kulit "pelı" sampai lama, apalagi yang digunakan air sadah, mengandung kalsium dan magne sum bikarbonat. Bahan kimia tersebut bereaksi dengan kapur dan membentuk suatı endapan kalsium karbonat dipermukaan kulit "pelt". Endapan tersebut mempenganihi rabaan bagian rajah, warna kulit setelah disamak dan di cat (5).

Proses menghilangkan kapur dengan bahan kimia adalah aman, mempercepat proses dan menghindari kesulitan-kesulitan (5). Bahan kimia yang biasa digunakan dalam proses pembuangan kapur adalah asam, garam asam dan garam ammonum (3.45.6.7). Proses menghilangkan kapur menggunakan asam lemah, terutama asam organik, adalah lebih aman dan memerlukan waktu lebih kurang satu jam (3)

"Drenching" adalah proses pembuangan kapur dari dalam kulit "pelt" dengan menggunakan sari dedak padi dan sejenisnya yang difermentasikan selanna satı malam atau lebih (4). Pada waktu fermentasi sari dedak padi dan jesenisnya. menghasilkan asam organik lemah, yaitu asam asetat, laktat, format dan butirat Juga menghasilkan karbon dioksida, oksigen, hidrogen dan nitrogen. $A$ sam asim organik lemah dan karbon dioksida hasil fermentasi mampu menghilangkan kapu dari dalam kulit "pelt" (4.5)

\section{MATERI DAN METODA}

Materi

Dalam penelitian ini menggunakan kulit "pelt" kambing sebanyak 14 lembar. sari dedak padi yang difermentasikan selama 5 hari, 10 hari dan 15 hari.

Alat-alat yang digunakan adalah drum penelitian, timbangan digital dan indikator phenolphthalein.

Metoda

Kulit "pelt" kambing sebanyak 14 lembar dibelah menjadi dua bagian menurut garis punggung. Selanjutnya dibagi menjadi tiga kelompok.

Sebelum proses pembuangan kapur dikerjakan, kulit "pelt" dicuci dengan air bersih dahulu selama 15 menit untuk menghilangkan kapur yang melekat dipermukatan kulit "pelt".

Kelompok pertama diproses pembuangan kapur menggunakan sari dedak padi yang difermentasikan selama 5 hari, kelompok kedua diproses pembuangan kapur menggunakan sari dedak padi yang difermentasikan selama 10 hari. Kelompok ketiga diproses pembuangan kapur menggunakan sari dedak padi yang difermentasikan selama 15 hari. Setiap perlakuan untuk setiap kelompoh menggunakan tiga tengahan lembar kulit "pelt" kambing, dengan dua kali ulangan Untuk setiap perlakuan proses pembuangan kapur menggunakan $100 \%$ sari dedah padi yang difermentasikan dihitung dari berat kulit "pelt", dan dikerjakan selam: 60 menit Pada akhir proses pembuangan kapur, penampang kulit "pelt" diperiks: dengan indikator phenolphthalein, untuk mengetahui sampai seberapa garis kapu terbentuk. Dengan demikian diketahui apakah proses pembuangan kapur telal sempuna atau belum.

\section{HASIL DAN PEMBAHASAN}

Guna mengetahui kemampuan sari dedak padi yang difermentasikan selam: 5 han, maka setelah proses pembuangan kapur selesai dikerjakan, penampang kul, "pelı" diperikasa dengan indikator phenolphthalein. Dari hasil pemerikasaan diketahui hahwa penampang kulit "pelt" masih herwarna merah, ini berarti kul "pelı" masih mengandung banyak kapur. Dengan demikian dapat dikatakan bahw sari dedak padi yang difermentasikan selama 5 hari masih kecil kemampuanny untuk menghilangkan kapur yang ada didalam kulit "pelt". Hal ini disebabkan karen: fermentasi sari dedak padi belum sempurna, yang mengakibatkan kemampuan untu menghilangkan kapur yang ada didalam kulit "pelt" juga kecil.

Pada proses pembuangan kapur dengan sari dedak padi yang difermentasika selana 10 hari, setelah proses pembuangan kapur selesai dikerjakan, penampan kulit "pelı" diperiksa dengan indikator phenolpthlein 
Dari hasil pemeriksaan diketahui bahwa penampang kulit "pelt" bagian tepi berwama putih dan bagian tengah berwarna merah jambu. Ini berarti ada sebagian kapur yang telah hilang dari dalam kulit "pelt". Dengan demikian dapat dikatakan bahwa sari dedak padi yang difermentasikan selama 10 hari telah memiliki kemampuan untuk menghilangkan kapur dari dalam kulit "pelt" Hal ini disebabkan karena fermentasi sari dedak padi lebih baik, sehingga pembentukan asam-asam organik lemah juga lebih baik. Dengan demikian mengakibatkan kemampuan untuk menghilangkan kapur yang ada didalam kulit "pelt" juga lebih besar.

Demikian pula proses pembuangan kapur dengan sari dedak padi yang difermentasikan selam 15 hari. Setelah proses pembuangan kapur selesai dikerjakan, penampang kulit "pelt" diperiksa dengan indikator phenolphthalein. Dari hasil pemeriksaan diketahui bahwa seluruh penampang kulit "pelt" berwarna putih. Ini berarti bahwa pembuangan kapur telah sempurna. Dengan demikian dapat dikatakan, bahwa sari dedak padi yang difermentasikan selama 15 hari, memiliki kemampuan untuk menghilangkan kapur dari yang ada didalam kulit "pelt" begitu besar. Hal ini disehabkan karena fermentasi sari dedak padi lebih sempurna, sehingga pembentu kan asam-asam organik lemah juga lebih sempurna. Akibatnya kemampuan untuk menghilangkan kapur dari dalam kulit "pelt" lebih sempurna pula.

Dari hasil penelitian diketahui, bahwa sari dedak padi yang difermentasikan selama 10 hari sudah mempunyai kemampuan untuk menghilangkan kapur dari dalam kulit "pelt", meskipun belum sempurna. Ada kemungkinan, apabila waktu untuk proses pembuangan air ditambah, hilangnya kapur dari dalam kulit "pelt" lebih banyak

\section{KESIMPULAN}

Dari hasil penelitian diambil kesimpulan sebagai berikut :

1. Sari dedak padi yang difermentasikan dapat digunakan dalam proses pembu angan kapur.

2. Fermentasi sari dedak padi dikerjakan minimum selama 10 hari.

3. Sari dedak padi yang difermentasikan selama 15 hari, memiliki kemampuan untuk menghilangkan kapur dari dalam kulit "pelt" lebih sempurna, apabila dibandingkan dengan yang difermentasikan selama 10 hari

\section{UCAPAN TERIMA KASIH}

Dengan selesainya penelitian mengenai "PENGGUNAAN FERMLN SARI DEDAK PADI UNTUK PROSES PEMBUANGAN KAPUR" dan tersusunnya ulisan ini, kami mengaturkan terimakasih kepada Bapak Kepala Balai Besar Penelitian dan Pengembangan Industri Barang Kulit, Karet dan Plastik beserta staf, atas fasilitas dan bantuannya berupa apapun, sehingga penelitian dapat dilaksanakan dan tersusunnya tulisan ini

Mudah-mudahan penelitian ini ada manfaatnya bagi industri kulit.

\section{DAFTAR PUSTAKA}

1. Balai Penelitian Kulit: Proses Penyamakan Kulit. Yogyakarta, 1972

2. Indofil Chemical Limited : I eather linishing Manual, Room and Ilass ('ompa ny, Nelson House 185 A Besant Road, Bombay 400.025

3. ()'Flaherty, F.,W.T. Roddy and R.M. Lollar : The (hemistry and Tecnology of leather, Robert I: Krieger Publishing Company, Huntington, New York 1978

4. Sarkar, K.T. : Theory and Practice of leather Manulacture, Anjoy Sorcar, 4 Se cond Avenue, Mahatma Gandhi Road, Madras $600(041,1981$

5. Sharphouse, J.H. : Ieather Technician's Hand Book, I eather Product Associa tion, 9 st Thomas Street, London Sei, 195')

6. Soenyot, R. : Penuntun tentang Penyamakan Kulit, Yogyakarta, 1959.

7 Thorstensen, T.C. : Practical Leather Techology. Robert 1: Krieger Publishung Company, Hungtinton New York, 1976. 